\title{
The Relationship between Sustainability- Oriented Innovation Practices and Organizational Performance: Empirical Evidence from Slovenian Organizations
}

\author{
Matjaž Maletič ${ }^{1}$, Damjan Maletič ${ }^{1}$, Jens J. Dahlgaard², Su Mi Dahlgaard-Park ${ }^{3}$, Boštjan Gomišček ${ }^{1 *}$
}

\author{
${ }^{1}$ University of Maribor, Faculty of Organizational Sciences, Kidričeva cesta 55a, SI-4000 Kranj, Slovenia; \\ matjaz.maletic@fov.uni-mb.si, damjan.maletic@fov.uni-mb.si, bostjan.gomiscek@fov.uni-mb.si (corresponding author) \\ ${ }^{2}$ Linköping University, Department of Management and Engineering, Sweden; jens.jorn.dahlgaard@liu.se \\ ${ }^{3}$ Lund University, Department of Service Management, Sweden; Su_Mi.Dahlgaard-Park@ism.lu.se
}

Background and Purpose - The purpose of this paper is to empirically analyse the effects of sustainability-oriented innovation practices on the overall organizational performance. Further, this paper also aims to advance understanding of the measurement of corporate sustainability practices with the focus on innovation dimensions.

Design/Methodology/Approach - The study uses data obtained from a survey of 116 organizations encompassing both the manufacturing and service industries in Slovenia. Descriptive statistics were used in order to determine the level of sustainability-oriented innovation practices deployment. Exploratory factor analysis was applied to extract the underlying factors and to provide a basis for assessing their reliability and validity. In addition, regression analysis was used to quantify the effect of sustainability practices on the organizational performance.

Results - Data analysis result showed that sustainability-oriented innovation practices are significantly associated with organizational performance. Therefore, empirical evidence from this research confirmed the premise that building innovation competencies and integrating innovation activities in organization's processes lead to performance benefits. This contributes to the debate about the potential for organizations to be sustainable and competitive.

Conclusion - The presented research on corporate sustainability provides important theoretical and practical insights on which the deployment of sustainability-oriented innovation practices are conducive to fostering a broader set of performance benefits. As such, managers should increase organizations' capacity for innovation which can be beneficial in terms of performance implications and achieving sustainability goals.

Keywords: corporate sustainability, sustainability-oriented innovation, organizational performance, empirical study

\section{Introduction}

The role of business in society has been a concern both of scholars and practitioners for a long time (Salzmann et al., 2005). In this sense, Delai and Takahashi (2013) points out that sustainable development actions and initiatives have become vital aspects for any organization. A sustainable organization is one that contributes to sustainable development by delivering simultaneously economic, social, and environmental benefits - the so-called triple bottom line (Hart and Milstein, 2003). Many authors have approached this issue by discussing the business case for corporate sustainability, including, Dyllik and Hockerts (2002) and Salzmann et al. (2005). In general, the business case empha-

Received: $13^{\text {th }}$ December 2013; revised: $16^{\text {th }}$ January 2014 ; accepted: $27^{\text {th }}$ January 2014 
sises that business processes directed at achieving sustainable development sense are necessary for the financial growth of an organization. The business case for sustainability is often used to provide motivations for an organization to integrate aspects of sustainability into business processes (Asif et al., 2011).

In addition, many studies have discussed the business case for a sustainability innovation (e.g. Wagner, 2008). In this regard, the challenge for business is to develop innovation strategies in order to respond to needs and expectations of a wide array of stakeholders (Ayuso et al., 2006) and at the same time justify economic rationale behind these sustainability activities (Schaltegger and Wagner, 2006). Furthermore, van Kleef and Roome (2007) suggest that developing competencies that foster innovation for sustainable development can be perceived as the basis of competitiveness. For example, these competencies can enable organizations to offer products and services that create value for customers and to generate new products and services, and therefore adapting to rapidly changing environment faster than competitors (van Kleef and Roome, 2007).

An improved understanding of the link between sustainability-oriented innovation practices and organizational performance does not just contribute to a debate about the business case for sustainability (Schaltegger and Wagner, 2006), but also contribute to the knowledge of measuring sustainability-oriented innovation activities (Pujari, 2006). However, few studies have empirically investigated the specific organizational performance outcomes concerning sustainability-oriented innovation.

Thus, the following research question is addressed in this study: Can an organization benefit by creating and deploying sustainability-oriented innovation practices? Therefore, this study adds to the emerging dialogue on corporate sustainability by empirically investigating the performance benefits of business activities that are directed towards sustainability through innovation.

The paper is structured as follows: firstly, the literature review that underpinned this research and the methodology employed to carry it out are presented in sections 2 and 3 , respectively. Then, in section 4 empirical evidence on the relation between sustainability-oriented innovation practices and organizational performance is presented. In section 5 , we conclude with a discussion of the results, implications, and issues for further research.

\section{Literature review}

\subsection{Sustainability practices}

Recognizing the multi-dimensional nature of sustainability, a rapidly growing literature documents a wide range of specific sustainability practices being implemented by organizations (see, for example, Hahn and Scheermesser,
2006; Collins et al., 2010; Maletic et al., 2011; Fairfield et al., 2011). One key starting point in the debate on sustainability management is the inclusion of stakeholders and the integration of their respective demands (Seuring and Gold, 2013), which is suggested to be a critical process that helps organizations to understand their key environmental and social impacts (Rocha et al., 2007). As far as corporate environmentalism is concerned, considerable attention has been paid in the literature to the eco-efficiency (Côté et al., 2006) in terms of reducing energy and material intensity, utilizing renewable energy sources, and in the context of emissions reduction of pollutants and waste minimization. Furthermore, apart from talking the environmental problems, many other practices aim at creating more sustainable workplaces by focusing on worker health and safety aspects, employee engagement, equity as well as quality of life (e.g. Hutchins and Sutherland, 2008). Employee centred sustainability practices are also related to the sustainability oriented organizational learning (Siebenhuner and Anold, 2007). Recently, literature has paid attention to the sustainabilityrelated innovation practices, predominantly through the search of the ways on how to manage product development in a more sustainable way (Hallstedt et al., 2013).

Therefore, a number of fields, such as corporate environmentalism, corporate social responsibility, stakeholder, stakeholder theory and sustainable development, have contributed to the expansion of corporate sustainability literature. Due to difficulties in defining the concept of corporate sustainability as well as the multidisciplinary nature of sustainability, there are different approaches in conceptualizing and operationalizing sustainability constructs. One of the most commonly used measures are derived from established sustainability indexes, such as the SAM Dow Jones Sustainability Index, the KLD Social Index or the GRI performance indicators. Most of these sustainability initiatives are developed as a normative frameworks or process guidelines (Ligteringen and Zadek, 2005).

\subsection{Organizational performance}

The concept of organizational performance in literature refers normally to financial aspects such as profit, return on assets (ROA), return on equity (ROE) and economic value added (EVA). While financial measures of performance are among the most widely used by businesses, many researchers have criticized the short-term thinking and emphasize the importance of the non-financial components of performance measurement (e.g. Kaplan, 1983; Otley, 1999). Consequently, as a response to relatively narrow point of view of performance measuring, a more balanced approaches of performance measurement systems (PMSs) to include financial and non-financial performance measures, as well as explaining cause-and-effect relationships between the various measures, and providing better insight in terms of links between PMS and organization's 
strategy have been proposed (Kaplan and Norton, 1996; Neely and Adams, 2000). Thus the two most well-known and frequently used models for performance management - the balanced scorecard and the European Foundation for Quality Management's (EFQM) Excellent Model - reflect the development. The key in developing these models is to construct the multiple organizational performance measures so that they are properly integrated and directed towards achieving organizational goals and strategy. Various Quality models, among others, Deming model and Malcom Baldridge model are some forerunners of the integrated performance management models of which focuses were paid in multiple performance variables. In line with these developments, Gomes et al. (2011) further suggest that organizations should (among other performance measures) also pay attention to softer performance measures, such as social responsibility. Based on corporate social performance and corporate financial performance, Fauzi et al. (2010) proposed a multi-dimensional concept of triple bottom line (TBL) as sustainable corporate performance.

Considering the academic perspective, a number of studies have applied different ways to measure organizational performance. As a result, different measures of overall organizational performance have been used to the same phenomenon, i.e. overall organizational performance. The most frequently used measures of organizational performance in empirical studies are financial performance, market performance, quality performance, product innovation, process innovation, operational performance and customer satisfaction (e.g. Lin and Kuo, 2011; Antony and Bhattacharyya, 2010; Fuentes-Fuentes et al., 2004). As pointed out by Tangen (2003), different performance dimensions may have to be combined to get a balanced and complete view of the organization's performance. For instance, Venkatraman and Ramanujan (1986) consider three aspects of performance, among them are financial performance, business performance, and organizational effectiveness and the later have been subsequently known as organizational performance. They suggested that a broader conceptualisation of the organizational performance would (in addition to financial indicators) include operational indicators as well when measuring the organizational performance. The operational indicators may include such measures as new product introduction, product quality, manufacturing value-added and marketing effectiveness.

\subsection{Sustainability and innovation}

As stated by Klewitz and Hansen (2013), the debate on organizations that strive to achieve the goals of sustainable development through innovation was initially focused on eco-innovations. In general, one can argue that eco-innovations include several dimensions, such as: design dimensions, user dimensions, product service dimensions, governance dimensions and the engagement of key stakeholders in the innovation process (Carrillo-Hermosilla et al., 2010). The ultimate goal of putting efforts to eco-innovations is to provide new business opportunities and contribute to a transformation towards a sustainable society (CarrilloHermosilla et al., 2010). Generally, eco-innovations can be divided in the three main categories, as follows (Rennings et al., 2006):

- Process innovations enable the production of a given amount of output (goods, services) with less input. The latter can be interpreted in terms of the eco-efficiency (Côté et al., 2006) which aims to reduce the material and energy intensity. Process innovations can be further subdivided into innovations in end-of-pipe technologies and innovation in integrated technologies categories (Rennings et al., 2006).

- Product innovations encompass the improvement of goods and services or the development of new goods categories (Rennings et al., 2006). It is suggested that most of the sustainability-oriented product/service innovations relate to incremental or evolutionary innovation (e.g. remanufactured products, recycled content, organic cotton-based clothing, and water-based paints) (Pujari, 2006).

- Organizational innovations include new forms of management systems. This could also include environmental management systems (Poksinska et al., 2003). More recently, the trend has moved towards holistic sustainability management system standards and guidelines (Maas and Reniers, 2013).

Lately, the debate on sustainability and innovation has expanded its focus to include a wide range of themes such as sustainability-related innovation (e.g. Wagner, 2008; Klewitz and Hansen, 2013), sustainable innovation (Boons et al., 2013), CSR-driven innovation (e.g. Hockerts, 2008) as well as the discussion regarding the development of more sustainable management systems (Maas and Reniers, 2013).

\section{Methods}

\subsection{Sample and data collection}

A survey questionnaire was mailed to the managers of a random sample of Slovenian organizations. To ensure a reasonable response rate, the survey was sent in two waves. The questionnaire with the cover letter indicating the purpose and significance of the study was emailed to target respondents. Managers were chosen because they were considered to be familiar with the implementation of sustainability practices and performance indicators.

A total of 116 usable responses were received from a sample of Slovenian organizations. The profile of the organizations and respondents is provided in Table 1. 
Table 1. Profile of the respondents in our sample

\begin{tabular}{llc}
\hline Sample distribution & & Percentage \\
\hline Respondent profile & Middle management & 38.6 \\
& Frontline management & 22.8 \\
& Top management & 21.1 \\
& Data not available & 17.5 \\
& Total & $100(\mathrm{~N}=116)$ \\
Organization profile (employees) & $0-5$ & 6.0 \\
& $5-50$ & 18.1 \\
& $50-250$ & 31.9 \\
& $250-500$ & 9.5 \\
& over 500 & 26.7 \\
& Data not available & 7.8 \\
Total & $\mathbf{1 0 0}(\mathbf{N}=\mathbf{1 1 4})$ \\
\hline
\end{tabular}

\subsection{Measures}

Independent variables: sustainability-oriented innovation practices. Although our study mostly used multi-item scales that were verified through various analyses, appropriate scale for sustainability-oriented innovation practices was not available. Hence, the domains of construct were identified via a thorough review of the literature. Several items were operationalized in relation to eco-innovation activities in product development process (e.g. Pujari, 2006), stakeholder integration in product development process (e.g. Seuring and Gold, 2013) as well as in relation to business process improvements (e.g. Côté et al., 2006).

The items measuring sustainability oriented learning and the development of competencies supporting innovation were developed based on the literature review related to sustainability and organizational learning (e.g. Lozano, 2011; Siebenhuner and Anold, 2007; van Kleef and Roome, 2007).

Therefore, a diverse range of operationalizations has emerged for the sustainability-oriented innovation practices. The complete items of these scales are presented in Table 2.

Dependent variable: organizational performance. While recognising that performance is multi-dimensional concept (Chenhall and Langfield-Smith, 2007), we designed our survey instrument to capture the most commonly studied dimensions of organizational performance. The organizational performance sub-constructs were operationalised by developing several items based on a literature review (e.g. Baird et al., 2011; Kaynak, 2003; Martensen et al., 2007; Prajogo and Sohal, 2003; Veleva and Ellenbecker, 2001; Hutchins and Sutherland, 2008). Therefore, we understand the concept of organizational performance to be composed of the following sub-constructs: financial and market performance, quality performance, innovation performance, environmental performance and social performance. A resulting four-item scale captures the extent to which organizations achieve business success. A four-item scale measures quality performance and captures the extent to which organizations have improved quality of their products and services during the last 3 years and meet customer satisfaction. A four-item scale measures innovation performance in terms of product and process innovation. A four-item scale measures environmental performance and captures the extent to which organizations achieve efficiency of material and energy consumption. Finally, a four-item scale measures social performance from the employee perspective (satisfaction, motivation and turnover ratio). The corresponding items for measuring the organizational performance are presented in Appendix A.

\section{Analysis and Results}

\subsection{Measurement and validation of constructs}

Sustainability-oriented innovation practices. The scales for measuring sustainability-oriented innovation practices were subjected into validity and reliability tests. The construct validity was assessed merely using exploratory factor analysis (EFA) based on oblique rotation (Direct Oblimin). The scale reliability was tested by calculating its Cronbach's alpha. Additionally, we performed corrected item-total correlations (CITCs) in order to strengthen validity and reliability results. The results of the validity and reliability test are presented in Table 2. The result of factor analysis supports the validity of the two sub-constructs as indicated by the amount of variance explained which exceeded $50 \%$, and the loading factors of all items within each scale exceeded 0.5 (Hair et al., 2010). 
Table 2. Scale validity and reliability

\begin{tabular}{|c|c|c|c|}
\hline Factor & Items & $\begin{array}{l}\text { Factor } \\
\text { loading }\end{array}$ & CITC \\
\hline \multirow[t]{9}{*}{ SOPPD } & We consider sustainability as an opportunity for product/service differentiation & .974 & .733 \\
\hline & $\begin{array}{l}\text { Multiple departments (such as marketing, manufacturing, and purchasing) are } \\
\text { working together on sustainability related initiatives }\end{array}$ & .761 & .610 \\
\hline & $\begin{array}{l}\text { The organization undertakes regularly business process reengineering with a focus } \\
\text { on green perspectives }\end{array}$ & .753 & .776 \\
\hline & $\begin{array}{l}\text { The organization makes improvements to radically reduce environmental } \\
\text { impacts of products and services' life-cycles }\end{array}$ & .714 & .773 \\
\hline & $\begin{array}{l}\text { Preliminary market assessments are made to obtain customers' view of green product } \\
\text { ideas }\end{array}$ & .655 & .626 \\
\hline & $\begin{array}{l}\text { We search for external sources (e.g. partners, customers, research institutions) of } \\
\text { knowledge in our search for innovative ideas related to sustainability }\end{array}$ & .643 & 668 \\
\hline & $\begin{array}{l}\text { *The organization is characterised by a learning culture stimulating innovation for } \\
\text { sustainability }\end{array}$ & .532 & .749 \\
\hline & $\begin{array}{l}\text { *The business processes are flexible allowing us to achieve high levels of } \\
\text { responsiveness towards key stakeholder needs and demands }\end{array}$ & .503 & .374 \\
\hline & $\begin{array}{l}\text { *The organization involves key non-market stakeholders issues (such as local com- } \\
\text { munities, general public, governments and NGOs) early in the product/service design } \\
\text { and development stage }\end{array}$ & .386 & .473 \\
\hline \multirow[t]{5}{*}{ SOICD } & We develop new competencies supporting innovation in the organization & -.931 & .752 \\
\hline & $\begin{array}{l}\text { We continuously try to strengthen innovation skills in key areas where we have no } \\
\text { prior experiences }\end{array}$ & -.851 & .755 \\
\hline & $\begin{array}{l}\text { The organization is constantly exploring new/different ways to understand the expec- } \\
\text { tations and requirements of key stakeholders }\end{array}$ & -.814 & 667 \\
\hline & We acquire innovative environmental-friendly technologies and processes & -.656 & .644 \\
\hline & $\begin{array}{l}\text { *The organization involves key market stakeholders (customers, suppliers) early in } \\
\text { the product/service design and development stage }\end{array}$ & -.484 & .496 \\
\hline
\end{tabular}

* Excluded from further analysis

SOPPD - sustainability-oriented process and product deployment

SOICD - sustainability-oriented innovation competencies deployment

As shown in Table 2, the results show two factors with eigenvalues greater than one, accounting for $58.168 \%$ of the variance (K-M-O statistic 0.891; Bartlett statistic 898.029; significance 0.000 ). Thus, a model with two factors may be adequate to represent the data. To ensure a convergent validity a cut-off value of 0.6 and above is considered in this study. The first factor shows the variables having a common underlying dimension of 'sustainability-oriented process and product deployment (SOPPD)'. The main variables, which load heavily on this factor, are related to the eco-innovation activities in product development process as well in relation to innovative sustainability solutions in business processes. The second factor, named 'sustainabilityoriented innovation competencies deployment (SOICD)', includes the variables related to developing new knowledge and skills aiming to foster sustainability-related innovations.

The alpha coefficients have the acceptable value ranging from 0.85 to 0.89 , with the lowest value for the variable SOICD and the highest value for the variable SOPPD. Therefore, the alpha value for each construct was well above the recommended value of 0.70 , which is considered satisfactory for exploratory research (Hair et al., 2010). As shown in Table 2, the corrected item-total correlation scores range from 0.37 to 0.78 . The rules of thumb suggest that the item-to-total correlations should exceed 0.5 (Hair et al., 2010). Accordingly, some items are considered to be excluded from further analysis (in table marked with an »*«). 
Organizational performance. Organizational performance measures were assessed via responses to the question 'Please select the number (on a 5-point Likert-type scale) that accurately reflects the extent of your organization's overall performance over the last three years on each of the following . The following dimensions of organizational performance were included in the questionnaire: financial and market performance, quality performance, innovation performance, environmental performance and social performance.

In order to confirm the latent factor structure for measured variables, an exploratory factor analysis (EFA) was performed using the principal components analysis (PCA) with the Varimax rotation method. The results show five factors with eigenvalues greater than one, accounting for $69.961 \%$ of the variance (K-M-O statistic 0.869; Bartlett statistic 1497.571; significance 0.000). In order to guarantee the convergent and discriminant validity, the low loading items $(<0.6)$ were excluded from the subsequent data analysis. Factor loading of organizational performance items are presented in Appendix A.

\subsection{Descriptive statistics}

Prior to further statistical analysis, we first investigated the descriptive statistics for study variables. Means, standard deviations, and bivariate correlations are presented in Table 3. Observing the overall sub-constructs, we can see that the highest mean value corresponds to the SOICD (3.94), while the lowest value corresponds to the financial and market performance (3.21). However, respondents' organizations appeared to be implementing sustainability-oriented innovation practices to a relatively strong extent (means of 3.89 and 3.94, respectively).
As expected, the results indicated positive relationships between sustainability-oriented innovation practices and all organizational performance dimensions, with correlations ranging from 0.32 to $0.56(\mathrm{p}<0.01)$. Furthermore, SOPPD shows the strongest correlation with the overall organizational performance $(\mathrm{r}=0.543, \mathrm{p}<.001)$, and the lowest correlation with the financial and market performance $(\mathrm{r}=$ $0.315, \mathrm{p}<.001)$. Regarding the SOICD, the strongest correlation was observed in the case of overall organizational performance $(r=0.543, p<.001)$, while the lowest value was found in the correlation between SOICD and environmental performance $(r=0.333, p<.001)$.

\subsection{Regression analysis}

First, mean scores were calculated from the scale's items to generate the composite scores for the organizational performance. This newly created composite variable was subsequently used in the regression analysis. Furthermore, the normality of the composite score was checked and the result indicated no major violation, with skewness and kurtosis values well within the accepted range ( \pm 1 and $<3$, respectively). Additionally, the Kolmogorov-Smirnov test of normality supports the aforementioned arguments (K-S $=0.057, \mathrm{p}=0.200$ ).

Table 4 summarises the regression results for the effects of sustainability-oriented innovation practices on the organizational performance.

The results in Table 4 show that the overall regression model is significant with an $\mathrm{F}$ value of $33.047(\mathrm{P}=0.000)$. Furthermore, to examine multi-collinearity, we calculated variance inflation factors (VIF) for the regression equation. The VIF for the Model 4 was 1.62, which is well below the rule-of-thumb cut-off of 10 (Field, 2005).

Table 3. Means, standard deviations and correlations

\begin{tabular}{|c|c|c|c|c|c|c|c|c|c|}
\hline & Mean & SD & (1) & (2) & (3) & (4) & (5) & (6) & (7) \\
\hline (1) $S O P P D$ & 3.89 & .76 & & & & & & & \\
\hline (2) SOICD & 3.94 & .75 & $.617^{* *}$ & & & & & & \\
\hline (3) Organizational performance & 3.48 & .66 & $.543^{* *}$ & $.561^{* *}$ & & & & & \\
\hline $\begin{array}{l}\text { (4) Financial and market perfor- } \\
\text { mance }\end{array}$ & 3.21 & .91 & $.315^{* *}$ & $.361^{* *}$ & $.829^{* *}$ & & & & \\
\hline (5) Quality performance & 3.81 & .68 & $.335^{* *}$ & $.459^{* *}$ & $.708^{* *}$ & $.526^{* *}$ & & & \\
\hline (6) Innovation performance & 3.48 & .96 & $.472^{* *}$ & $.510^{* *}$ & $.847^{* *}$ & $.686^{* *}$ & $.504^{* *}$ & & \\
\hline (7) Environmental performance & 3.54 & .82 & $.494^{* *}$ & $.333^{* *}$ & $.709^{* *}$ & $.464^{* *}$ & $.347^{* *}$ & $.493^{* *}$ & \\
\hline (8) Social performance & 3.33 & .86 & $.479^{* *}$ & $.494^{* *}$ & $.752^{* *}$ & $.478^{* *}$ & $.481^{* *}$ & $.520^{* *}$ & $.424^{* *}$ \\
\hline
\end{tabular}

**. Correlation is significant at the 0.01 level (2-tailed). 
Table 4. Results of regression analysis: SOPPD, SOICD, and organizational performance

\begin{tabular}{ll}
\hline \multicolumn{2}{l}{ Dependent: organizational performance } \\
\hline & Model \\
\hline SOPPD & $0.315^{* *}$ \\
SOICD & $0.364^{* *}$ \\
$\mathrm{R}^{2}$ & 0.375 \\
Adjusted $\mathrm{R}^{2}$ & 0.364 \\
F & 33.047 \\
P-value of overall model & 0.000 \\
\hline
\end{tabular}

$* * P<0.01$

As shown in Table 4, the results of the regression analysis suggest that both sub-constructs of sustainabilityoriented innovation practices have a significant relationship with organizational performance $(\beta=0.315, \mathrm{p}<0.01 ; \beta=$ $0.364, \mathrm{p}<0.01$ respectively). $\mathrm{R}$ square shows that $38 \%$ of the variation in organizational performance is explained by the sustainability-oriented innovation practices. Thus, the basic premise which suggests a positive relationship between sustainability practices and organizational performance is supported.

\section{Discussion and conclusions}

Debates relating to corporate sustainability are becoming important subjects of the wide range of management literature in this century (Asif et al., 2011). Organizations are confronted with environmental and social issues in their decisions, not only to take into account moral and legal responsibility that need to be encouraged (Takala and Pallab, 2000), but also to ensure sustainable economic success (Wagner, 2010; Koo et al., 2013). Although researchers have widely discussed the relevant issues of sustainability-oriented innovation (e.g. Wagner, 2008; Klewitz and Hansen, 2013), there is a lack of empirical evidence on the relationship between these activities and overall organizational performance. To fill this existing research gap, this research proposed a novel construct - sustainability-oriented innovation practices - and developed a research framework to further discuss the effect of these practices on the organizational performance.

Furthermore, our study underscores previous assertions that organizations can benefit from pursuing sustainability (e.g. Schaltegger and Wagner, 2006). The results of the regression analysis have confirmed the premise that sustainability practices positively influence the organizational performance. As such, the study provides empirical evidence indicating that organization can benefit by obtaining and deploying sustainability-oriented innovation practices. In particular, the results of this study suggest that organizational learning in terms of developing new sustainability- oriented innovation competencies can provide superior performance benefits to the organization. Indeed, several prior studies have suggested that organizational learning with regard to innovation can contribute positively to the sustainability (e.g. Lozano, 2011; Siebenhuner and Anold, 2007). In this regard we can argue that developing capabilities and, therefore, acquiring the intangible assets, is essential for future growth and it is needed to successfully integrate and embed the sustainability in every aspect of the organization.

Furthermore, the results of this study indicate that organizations can benefit from integrating sustainability aspects in their products and processes, as reflected by the positive and significant effect of SOPPD on the organizational performance. These findings are somewhat supporting the argument that incorporating sustainability activities in product and process development can provide tools and mechanisms to organizations to enhance their economic benefits without affecting environment and communities (Pujari, 2006; Schrettle et al., 2013). Therefore, our study leads us to suggest that organizations should built sustainability aspects into tangible and intangible product/process quality characteristics, through a constant focus on stakeholders' wants and needs, and on the basis of principles of continuous improvement.

\subsection{Theoretical contributions and managerial implications}

While drawing on earlier work on performance implications of sustainability management activities (e.g. Wagner, 2008), this research contributes to the literature by focusing on the link between sustainability-oriented innovation practices and organizational performance (e.g. Antony and Bhattacharyya, 2010). Seen in this context, the main theoretical contribution of this study is reflected through the proposal of a novel construct - sustainability-oriented innovation practices - and the successful verification of the effect of these practices on the organizational performance. Additionally, this study considered "sustainability-oriented process and product deployment" and "sustainability-oriented innovation competencies deployment" as the two sub-dimensions of the newly developed construct. This is significant because so far there are only a few empirically based studies that investigate sustainability-related innovations and its performance implications. In this regard, this work can contribute to a better understanding of the underlying dimensions of sustainability-oriented innovation and its relationship with the overall organizational performance. The developed research framework and empirical evidence from this study can provide useful reference for further studies to investigate the relevant literature regarding corporate sustainability, innovation, and performance.

In addition, our results also have significant managerial implications. First, organization's competitive advantage can be achieved by focusing on its environment, includ- 
ing its customers' needs and other stakeholders' demands as well as by interacting with potential partners. Among others, this also requires from organization to change the view of the customer from a passive participant to an active contributor in product development (Witell et al., 2011). Therefore, managers should encourage employees to understand stakeholders' present and future needs as well as to pursue knowledge that is outside the scope of their organization. Considering the intra-organizational creation of new knowledge, managers should take into account crossfunctional integration in order to enable employees to share existing knowledge and develop new sustainability-oriented innovation competencies.

Second, the capability of an organization to create innovative and sustainable solutions (i.e. process innovations, product innovations and service innovations) can be viewed as organizational resource. Therefore, managers should establish an efficient mechanism to sustain this asset and effectively use it to enhance performance and gain competitive advantages. Accordingly, managers should strive to achieve sustainable innovation excellence in terms of developing innovative new products or services in a way which both in the short term and in the long run satisfies the customers and other stakeholders, such as employees, suppliers and society, in a balanced way (Dahlgaard-Park and Dahlgaard, 2010).

\subsection{Limitations and future studies}

As with all empirical studies, there are a number of limitations and directions for future research. First, the scales that were used to measure the construct 'sustainability-oriented innovation practices' capture only limited dimensions of innovation-related themes. Future research needs to examine the usefulness of additional measures. Secondly, due to a relatively small sample size, care should be taken while generalizing the results. Future research on sustainabilityoriented innovation could also be more specific in estimating the relative contribution of each of the sub-constructs to the particular dimension of organizational performance (e.g. comparison of the effects of SOPPD and SOICD on the financial and market performance). Therefore, the results of this study can stimulate further development of theory building and conceptual development within the interdisciplinary field of corporate sustainability, quality management, innovation, and performance.

\section{References}

Antony, J.P. \& Bhattacharyya, S. (2010). Measuring organizational performance and organizational excellence of SMEs - Part 1: a conceptual framework. Measuring Business Excellence, 14(2), 3-11, http://dx.doi.org/10.1108/13683041011047812
Asif, M., Searcy, C., Garvare, R. \& Ahmad, N. (2011). Including sustainability in business excellence models. Total Quality Management \& Business Excellence, 22(7), 773-786, http:// dx.doi.org/10.1080/14783363.2011.585784

Ayuso, S., Rodríguez, M.Á. \& Ricartm, J.E. (2006). Responsible competitiveness at the "micro" level of the firm. Using stakeholder dialogue as a source for new ideas: a dynamic capability underlying sustainable innovation. Corporate Governance, 6(4), 475-490, http://dx.doi.org/10.1108/14720700610689586

Baird, K., Hu, K.J. \& Reeve, R. (2011). The relationships between organizational culture, total quality management practices and operational performance. International Journal of Operations \& Production Management, 31(7), 789-814. http://dx.doi. org/10.1108/01443571111144850

Boons, F., Montalvo, C., Quist, J. \& Wagner, M. (2013). Sustainable innovation, business models and economic performance: an overview. Journal of Cleaner Production, 45, 1-8, http:// dx.doi.org/10.1016/j.jclepro.2012.08.013

Carrillo-Hermosilla, J., Río, P. \& Könnölä, T. (2010). Diversity of eco-innovations: Reflections from selected case studies. Journal of Cleaner Production, 18, 1073-1083, http://dx.doi. org/10.1016/j.jclepro.2010.02.014

Chenhall, R.H. \& Langfield-Smith, K. (2007). Multiple Perspectives of Performance Measures. European Management Journal, 25(4), 266-282, http://dx.doi.org/10.1016/j.emj.2007.06.001

Côté, R., Booth, A. \& Louis, B. (2006). Eco-efficiency and SMEs in Nova Scotia, Canada. Journal of Cleaner Production, 14, 542-55, http://dx.doi.org/10.1016/j.jclepro.2005.07.004

Collins, E., Roper, J. \& Lawrence, S. (2010). Sustainability Practices: Trends in New Zealand Businesses. Business Strategy and the Environment, 19, 479-494, http://dx.doi. org/10.1002/bse.653

Dahlgaard-Park, S.M. \& Dahlgaard, J.J. (2010). Organizational learnability and Innovability: A system for assessing, diagnosing and Improving Innovations. International Journal of Quality and Service Sciences, 2(2), 153-174. http://dx.doi. org/10.1108/17566691011057339

Delai, I. \& Takahashi, S. (2013). Corporate sustainability in emerging markets: insights from the practices reported by the Brazilian retailers. Journal of Cleaner Production, 47, 211221, http://dx.doi.org/10.1016/j.jclepro.2012.12.029

Dyllik, T. \& Hockerts, K. (2002). Beyond the business case for corporate sustainability. Business Strategy and the Environment. 11(2), 30-141, http://dx.doi.org/10.1002/bse.323

Fairfield, K.D., Harmon, J. \& Behson, S.J. (2011). Influences on the organizational implementation of sustainability: an integrative model. Organization Management Journal, 8, 4-2, http://dx.doi.org/10.1057/omj.2011.3

Fauzi, H, Svensson, G. \& Rahman, A.A. (2010). "Triple Bottom Line" as "Sustainable Corporate Performance": A Proposition for the Future. Sustainability, 2, 1345-1360, http://dx.doi. org/10.3390/su2051345

Field, A. (2005). Discovering Statistics Using SPSS (Introducing Statistical Methods series). London: Sage Publications Ltd; Second Edition.

Fuentes-Fuentes, M.M., Albacete-Sáez, C.A. \& Lloréns-Montes, F.J. (2004). The impact of environmental characteristics on TQM principles and organizational performance. Omega, 32, 425-442, http://dx.doi.org/10.1016/j.omega.2004.02.005

Gomes, C.F., Yasin, M.M. \& Lisboa, J.V. (2011). Performance measurement practices in manufacturing firms revisited. 
InternationalJournalofOperations \& Production Management, 31(1), 5-30, http://dx.doi.org/10.1108/01443571111098726

Hahn, T. \& Scheermesser, M. (2006). Approaches to Corporate Sustainability among German Companies. Corporate Social Responsibility and Environmental Management, 13, 150-165, http://dx.doi.org/10.1002/csr.100

Hair, J.F.Jr., Black, W.C., Babin, B.J. \& Anderson, R.E. (2010). Multivariate Data Analysis, 7th ed. London: Pearson Prentice Hall.

Hallstedt, S.I., Thompson, A.W. \& Lindahl, P. (2013). Key elements for implementing a strategic sustainability perspective in the product innovation process. Journal of Cleaner Production, 51, 277-288, http://dx.doi.org/10.1016/j.jclepro.2013.01.043

Hart, S.L. \& Milstein, M.B. (2003). Creating sustainable value. Academy of Management Executive, 17(2), 56-69, http:// www.jstor.org/stable/4165956

Hockerts, K., Morsing, M., Eder-Hansen, J., Krull, P., Midttun, A., Halme, M., Sweet, S., Davidsson, P., Sigurjonsson, T. O., \& Nurmi, P. (2008). CSR-Driven Innovation: Towards the Social Purpose Business. Frederiksberg: Center for Corporate Social Responsibility, CBS. Retrieved from: http://samfundsansvar. $\mathrm{dk} /$ file/318859/csr_driven_innovation_towards_social_purpose_business_september_2008..pdf

Hutchins, J. \& Sutherland, J.W.'. (2008). An exploration of measures of social sustainability and their application to supply chain decisions. Journal of Cleaner Production, 16, 16881698, http://dx.doi.org/10.1016/j.jclepro.2008.06.001

Kaplan, R.S. \& Norton, D.P. (1996). The Balanced Scorecard: Translating Strategy into Action. Boston: Harvard Business School.

Kaplan, R.S. (1983). Measuring manufacturing performance: a new challenge for managerial accounting research. Accounting Review, 58(4), 686-703, http://www.jstor.org/stable/247063

Kaynak, H. (2003). The relationship between total quality management practices and their effects on firm performance. Journal of Operations Management, 21, 405-435, http:// dx.doi.org/10.1016/S0272-6963(03)00004-4

Klewitz, J. \& Hansen, E.G. (2013). Sustainability-oriented innovation of SMEs: a systematic review. Journal of Cleaner Production, http://dx.doi.org/10.1016/j.jclepro.2013.07.017

Koo, C., Chung, N. \& Ryoo, S.Y. (2013). How does ecological responsibility affect manufacturing firms' environmental and economic performance? Total Quality Management \& Business Excellence, http://dx.doi.org/10.1080/14783363.20 13.835615

Lingteringen, E. \& Zadek, S. (2005). The Future of Corporate Responsibility Codes, Standards and Frameworks. Executive Briefing. GRI and AccountAbility, 4.

Lin, C.Y. \& Kuo, T.H. (2007). The mediate effect of learning and knowledge on organizational performance. Industrial Management \& Data Systems, 107(7), 1066-1083, http:// dx.doi.org/10.1108/02635570710816748

Lozano, R. (2011). Creativity and Organizational Learning as Means to Foster Sustainability. Sustainable Development, http://dx.doi.org/10.1002/sd.540

Maletic, M., Maletic, D. \& Gomiscek, B. (2011). Can sustainable quality management contribute to the organizational performance? African Journal of Business Management, 5(9), 3723-3734, http://dx.doi.org/10.5897/AJBM10.1575

Martensen, A., Dahlgaard, J.J., Park-Dahlgaard, S.M. \& Grønholdt, L. (2007). Measuring and diagnosing innovation excel- lence - simple contra advanced approaches: a Danish study. Measuring Business Excellence, 11(4), 51-65, http://dx.doi. org/10.1108/13683040710837928

Maas, S. \& Reniers, G. (2013). Development of a CSR model for practice: Connecting five inherent areas of sustainable business. Journal of Cleaner Production, http://dx.doi. org/10.1016/j.jclepro.2013.07.039

Neely, A. \& Adams, C. (2000). Perspectives on performance: the performance prism. In Bourne, M. (Ed.), Handbook of Performance Measurement, Gee Publishing, London.

Otley, D. (1999). Performance management: A framework for management control systems research. Management Accounting Research, 10 (4), 363-382, http://dx.doi.org/10.1006/ mare.1999.0115

Poksinska, B., Dahlgaard, J.J. \& Eklund, J.A.E. (2003). Implementing ISO 14000 in Sweden: motives, benefits and comparisons with ISO 9000. International Journal of Quality \& Reliability Management, 20(5), 585-606, http://dx.doi. org/10.1108/02656710310476543

Prajogo, D.I. \& Sohal, A.S. (2003). The relationship between TQM practices, quality performance, and innovation performance An empirical examination. International Journal of Quality \& Reliability Management, 20(8), 901-918, http://dx.doi. org/10.1108/02656710310493625

Pujari, D. (2006). Eco-innovation and new product development: understanding the influences on market performance. Technovation, 26, 76-85, http://dx.doi.org/10.1016/j.technovation.2004.07.006

Rennings, K., Ziegler, A., Ankele, K. \& Hoffmann, E. (2006). The influence of different characteristics of the EU environmental management and auditing scheme on technical environmental innovations and economic performance. Ecological Economics, 57, 45-59, http://dx.doi.org/10.1016/j. ecolecon.2005.03.013

Rocha, M., Searcy, C. \& Karapetrovic, S. (2007). Integrating Sustainable Development into Existing Management Systems. Total Quality Management \& Business Excellence, 18(1-2), 83-92, http://dx.doi.org/10.1080=14783360601051594

Salzmann, O., Ionescu-Somers, A. \& Steger, U. (2005). The Business Case for Corporate Sustainability: Literature Review and Research Options. European Management Journal, 23(1), 27-36, http://dx.doi.org/10.1016/j.emj.2004.12.007

Schaltegger, S. \& Wagner, M. (2006). Managing and measuring the business case for sustainability: Capturing the relationship between sustainability performance, business competitiveness and economic performance. In S. Schaltegger \& M. Wagner, (eds) Managing the business case for sustainability: The integration of social, environmental and economic performance, pp. 1-27. Sheffield: Greenleaf.

Schrettle, S., Hinz, A., Scherrer -Rathje, M. \& Friedli, T. (2013). Turning sustainability into action: Explaining firms' sustainability efforts and their impact on firm performance. International Journal of Production Economics, 147, 73-84, http://dx.doi.org/10.1016/j.ijpe.2013.02.030

Seuring, S. \& Gold, S. (2013). Sustainability management beyond corporate boundaries: from stakeholders to performance. Journal of Cleaner Production, 56, 1-6, http://dx.doi. org/10.1016/j.jclepro.2012.11.033

Siebenhuner, B. \& Anold, M. (2007). Organizational learning to manage sustainable Development. Business Strategy and the Environment, 16, 339-353, http://dx.doi.org/10.1002/bse.579 
Takala, T. \& Pallab, P. (2000). Individual, Collective and Social Responsibility of the Firm. Business Ethics: A European Review, 9(2), 109-118, http://dx.doi.org/10.1111/14678608.0018

Tangen, S. (2003). An overview of frequently used performance measures. Work Study. 52(7): 347-54, http://dx.doi. org/10.1108/00438020310502651

van Kleef, J.A.G. \& Roome, N.J. (2007). Developing capabilities and competence for sustainable business management as innovation: a research agenda. Journal of Cleaner Production, 15, 38-51, http://dx.doi.org/10.1016/j.jclepro.2005.06.002

Veleva, V. \& Ellenbecker, M. (2001). Indicators of sustainable production: framework and methodology. Journal of Cleaner Production, 9, 519-549, http://dx.doi.org/10.1016/S09596526(01)00010-5

Venkatraman, N. \& Ramanujam, V. (1986). Measurement of business performance in strategy research: a comparison of approaches. Academy of Management Review, 11(4), 801-14, http://www.jstor.org/stable/258398

Weber, M. (2008). The business case for corporate social responsibility: A company-level measurement approach for CSR. European Management Journal, 26, 247- 261. http://dx.doi. org/10.1016/j.emj.2008.01.006

Wagner, M. (2010). The role of corporate sustainability performance for economic performance: A firm-level analysis of moderation effects. Ecological Economics, 69, 1553-1560, http://dx.doi.org/10.1016/j.ecolecon.2010.02.017

Wagner, M. (2008). Links between sustainability-related innovation and sustainability management. SFB 649 Discussion Paper 2008-046. Berlin: Technische Universität München. Retrieved, April 13 from http://sfb649.wiwi.hu-berlin.de/ papers/pdf/SFB649DP2008-046.pdf

Witell, L., Löfgren, M. \& Gustafsson, A. (2011). Identifying ideas of attractive quality in the innovation process. The TQM Journal, 23(1), 87-99, http://dx.doi.org/10.1108/17542731111097515

Matjaž Maletič is a teaching assistant at Faculty of Organizational Sciences, University of Maribor. His main research interest concerns the quality management, corporate sustainability, integration of quality management and sustainability as well as the overall organizational performance. He holds a bachelor's degree in Wood Science and Technology (University of Ljubljana) and Organization (University of Maribor). He has defended his PhD thesis in September 2013 at the University of Maribor, Faculty of Organizational Sciences.

Damjan Maletič is teaching assistant and researcher at the Faculty of Organizational Sciences, University of Maribor. His research activities are mainly devoted to the fields of maintenance management and quality management. At present, his research is focused on studying the interaction between quality management, production and maintenance performance. He holds a bachelor's degree in Wood Science and Technology (University of Ljubljana) and Organization (University of Maribor). $\mathrm{He}$ is currently a PhD student at the University of Maribor, Faculty of Organizational Sciences.

Jens J. Dahlgaard is Professor Emeritus and previously chair professor at the Division of Quality Technology and Management at Linköping University, Sweden, and before that he was chair professor at Department of Quality Management at the Aarhus School of Business, Denmark where he build up the first master program in Quality Management in Europe. During this period he was also active as one of the founders of The Danish Quality Award and also one of the founders of EUN.TQM (European University Network in TQM). He has received several awards and has been invited as distinguished visiting professor at many European and Asian universities. He is a member of the International Academy for Quality (IAQ), he is also elected as the first president of EAQS (European Academy for Quality Sciences). He has published 15 books and over 100 research articles. He serves on the editorial boards of several international journals and is currently editor of the journal Total Quality Management \& Business Excellence (TQM\&BE). Professor Dahlgaard is one of the founders and chairman of the yearly QMOD conferences (Quality Management and Organisational Development) - one of the world's largest research conferences on Quality and Service Sciences.

Su Mi Dahlgaard-Park is currently professor at Institute of Service Management, Lunds University, Sweden. Her research areas have been HRM, Quality Management, Organization Theory, Learning and Knowledge Management, and Organizational Change. Within these areas she has published more than 100 research papers and numerous books. She is elected as academician of IAQ (International Academy for Quality) and co-founder and co-chair of the International QMOD/ ICQSS (Quality Management and Organizational Development) Conference during the last 13 years. She is a frequent keynote speaker at International conferences and has been invited as distinguished visiting professor in many European and Asian universities.

Boštjan Gomišček is associate professor at the University of Maribor, Faculty of Organizational Sciences, Slovenia. As head of the Laboratory for Quality Management he is predominantly engaged in the following research fields: quality management, maintenance management and environmental protection. 


\section{Appendix A}

\section{Measurement items - organizational performance}

Financial and market performance

Factor

loadings

0.587

*PERF1. Return on investment (ROI) has increased above industry average during the last 3 years

0.833

PERF2. Sales growth has increased above industry average during the last 3 years

0.799

0.750

PERF4. Market share has increased during the last 3 years

\section{Quality performance}

*PERF5. The quality of our products and services has been improved during the last 3 years

0.516

PERF6. Customer satisfaction has increased during the last 3 years

0.634

PERF7. Customer complaints has decreased during the last 3 years

0.859

PERF8. The cost of poor quality has decreased during the last 3 years

Innovation performance

PERF9. The organization has introduced more innovative products and services than our main competitors dur- 0.730 ing the last 3 years

PERF10. Our new products and services are perceived by our customers as innovative

0.714

PERF11. The speed of adoption of new technology is faster than at our main competitors

0.690

*PERF 12 . The number of innovations that provide the organization with a sustainable competitive advantage 0.570 has increased during the last 3 years

\section{Environmental performance}

PERF13. The efficiency of the consumption of raw materials has improved during the last 3 years

0.717

PERF14. The resource consumption (thermal energy, electricity, water) has decreased (e.g. per unit of income, 0.758 per unit of production, ...) during the last 3 years

PERF15. The percentage of recycled materials has increased during the last 3 years

PERF16. The waste ratio (e.g. kg per unit of product, $\mathrm{kg}$ per employee per year) has decreased during the last 3 years

0.696

$$
\text { Social performance }
$$

PERF17. The turnover ratio has decreased during the last 3 years

PERF18. The employees' satisfaction has increased during the last 3 years

PERF19. The employees' motivation has increased during the last 3 years

0.760

*PERF 20. Health and safety performance has improved during the last 3 years

0.665

*PERF 21. Employee education and training (man-days per employee per year) have increased during the last 3 years

0.539 